\title{
PERSENTASE BUAH JADI PADA PERSILANGAN KELAPA GENJAH SALAK DENGAN KELAPA DALAM MAPANGET (GSK x DMT)
}

\section{Semuel D. Runtunuwu ${ }^{1,2}$, Jantje Pongoh ${ }^{1}$, Heldering Tampake ${ }^{3}$, dan Yefta Pamandungan ${ }^{4}$}

\footnotetext{
${ }^{1}$ Lab. Genetika dan Pemuliaan Tanaman, Fakultas Pertanian UNSRAT, ${ }^{2}$ Lab. Fisiologi Tanaman Fakultas Pertanian UNSRAT, ${ }^{3}$ Lab. Pemuliaan Tanaman, BALITKA Mapanget, ${ }^{4}$ Mahasiswa Jurusan Budidaya Pertanian Fakultas Pertanian UNSRAT
}

\begin{abstract}
Runtunuwu, S.D., et. al. 2007. The Become Fruit Rate in Crossing Coconut Genjah Salak x Dalam Mapanget (GSK x DMT). Eugenia 13 (1) : 97-108.

The aim of this research was 1) individu tree crossing of coconut Genjah Salak x Dalam Mapanget (GSK $\times$ DMT), 2) to known the become fruit rate in crossing individu tree of coconut GSK $\times$ DMT. The method of crossing used crossing a pair between fourteen trees individu of coconut GSK. With three trees coconut DMT, so it become fourty two combination crossing

Coconut DMT 1188 crossing with stem number one of coconut GSK, DMT 1172 with stem number two coconut GSK and DMT 781 with stem number three. The become fruit rate of the crossing result between fourteen individu trees of coconut GSK and tree individu trees of DMT with the tree number 1188 , 1172 and 781 in three mounth in sequence was have variation from $0,00-27,27 \%, 3,76-32 \%$ and $2,86-$ $27,16 \%$. Therefore the lowest success rate of these crossing was in combination of GSK coconut tree number fourteen and DMT tree number 1188 was $0,00 \%$, while the highest success rate was in the combination crossing between coconut GSK tree number 12 and DMT tree number 1172 was $32 \%$.
\end{abstract}

Keywords : coconut, fruit rate, crossing

\section{PENDAHULUAN}

Indonesia diperkirakan merupakan daerah asal kelapa. Diduga ada 500 kultivar kelapa yang berbeda dari segi morfologi dan tersebar di seluruh wilayah Indonesia. Kultivar-kultivar kelapa yang telah berhasil dikoleksi sampai tahun 2003 sebanyak 124 aksesi, diantaranya adalah kelapa Dalam seperti kelapa Dalam Tenga (DTA), kelapa Dalam Palu (DPU), kelapa Dalam Bali (DBI) dan kelapa Dalam Mapanget (DMT) serta terdapat juga golongan kelapa Genjah seperti kelapa Genjah Kuning Nias (GKN), kelapa Gen- jah Hijau Nias (GHN), kelapa Genjah Raja (GRA), dan kelapa Genjah Salak (GSK) (Novarianto 2003). Kultivar kelapa tersebut telah dilepas sebagai kelapa unggul nasional (Tampake 2005. Komunikasi pribadi).

Balai Penelitian Tanaman Kelapa dan Palma Lain (BALITKA) Mapanget sebagai institusi yang melakukan pengembangan tanaman kelapa, telah melakukan kegiatan pemuliaan untuk mendapatkan kelapa yang berproduksi tinggi, cepat berbuah, dan tahan penyakit Phytophthora (Novarianto 2002). Kelapa hibrida yang telah dihasilkan oleh BALITKA 
adalah kelapa Hibrida KHINA-1, KHINA2, dan KHINA-3. Kelapa Hibrida KHINA-1 adalah hasil persilangan antara kelapa Genjah Kuning Nias dengan Dalam Tenga (GKN x DTA), kelapa Hibrida KHINA2 adalah hasil persilangan antara kelapa Genjah Kuning Nias dengan Dalam Bali (GKN x DBI), dan kelapa Hibrida KHINA3 merupakan hasil persilangan antara kelapa Genjah Kuning Nias dengan Dalam Palu (GKN x DPU). Keunggulan dari ketiga kelapa Hibrida ini adalah berbuah cepat, yaitu berkisar 28 - 32 bulan dengan produksi kopra tinggi berkisar $3,00-3,40$ ton kopra/ha/tahun (Tenda, Lengkey, dan Kumaunang 1997).

Walaupun demikian, persilangannya dilakukan secara bulk sehingga terdapat keragaman di antara individu pohon kelapa hibrida yang dihasilkan. Di samping itu, tetua betina kelapa hibrida yaitu kelapa GKN ternyata rentan terhadap penyakit gugur buah. Oleh karena itu perlu dicari kelapa Genjah lainnya sebagai tetua yang tahan terhadap penyakit Phytophthora. Kelapa Genjah yang tahan terhadap penyakit Phytophthora adalah kelapa Genjah Salak (GSK) (Runtunuwu dkk. 1999).

Kelapa Genjah Salak (GSK) memiliki beberapa keunggulan, yaitu berbuah cepat (12 - 24 bulan), jumlah buah banyak (140 butir/pohon/tahun), produksi kopra banyak (4 ton kopra/ha/tahun) (Novarianto, Miftahorrachman dan Kumaunang 1997).

Kelapa Dalam Mapanget (DMT) juga merupakan alternatif tetua jantan yang telah berhasil dikarakterisasi dan memiliki keunggulan yaitu jumlah buah per pohon per tahun banyak (70 - 100butir), berat kopra per pohon tinggi $(23 \mathrm{~kg})$, produksi kopra tinggi (3,5 ton/ha/tahun) dan tahan terhadap penyakit Phythopthora (Novarianto dkk. 1997).

Berdasarkan hasil karakterisasi BALITKA ternyata kelapa Genjah Salak (GSK) dan kelapa Dalam Mapanget (DMT) sangat potensial untuk dijadikan sebagai tetua dalam perakitan kelapa Hibrida (Novarianto dkk. 1997).

Penelitian ini bertujuan untuk : 1). Menyilangkan kelapa Genjah Salak dengan kelapa Dalam Mapanget (GSK x DMT) secara individu pohon, dan 2). Mengetahui persentase buah jadi hasil persilangan secara individu pohon kelapa GSK x DMT

Hasil penelitian ini diharapkan dapat memberikan informasi mengenai persentase jumlah buah jadi pada persilangan kelapa GSK x DMT secara individu pohon.

\section{METODE PENELITIAN}

\section{Waktu dan Tempat Penelitian}

Penelitian ini telah dilaksanakan selama lima bulan yaitu dari bulan November 2005 sampai dengan April 2006 di keuun koleksi plasma nutfah BALITKA Kima Atas.

\section{Bahan dan Alat}

Bahan tanaman yang diamati adalah kelapa Genjah Salak (GSK) yang dikoleksi dari Desa Pematang Panjang, Kecamatan Sungai Tabuk, Propinsi Kalimantan Selatan. Tanaman yang disilangkan sebanyak 14 individu pohon kelapa GSK sebagai tetua betina yang telah diseleksi dari 66 individu pohon kelapa dan memiliki kesamaan genetik yang besar berdasarkan produksi bunga betina (Sual 2005), dan hasil analisis kesamaan genetik individu pohon kelapa berdasarkan penanda RAPD (Singkoh 2005). Keem- 
pat belas pohon kelapa tersebut adalah kelapa nomor pohon $7,8,10,12,14,20$, $28,32,41,47,49,64,65$ dan 66 . Selain itu, diamati juga kelapa GSK nomor pohon 6, 50 dan 70 sebagai kontrol. Untuk kelapa Dalam Mapanget (DMT), diamati 3 individu pohon kelapa Dalam Mapanget (DMT) sebagai tetua jantan yang telah diseleksi berdasarkan produksi buah terbanyak yaitu kelapa nomor pohon 1188 (93 butir per tahun), kelapa nomor pohon 1172 (85 butir/tahun), dan kelapa nomor pohon 781 (83 butir/tahun) (Tampake 2005. Komunikasi pribadi). Bahan lain yang digunakan adalah agar, aquades, sukrosa dan asam borat.

Adapun alat-alat yang digunakan untuk prosesing polen yaitu; tangga, pisau, kuas kecil, cook plate, gelas piala, petridish, mikroskop, gilingan kayu, oven, ayakan, label dan alat tulis menulis, dan untuk persilangan yaitu; tangga, kerodong, pisau, kuas kecil, cat pilox dan alat tulis menulis.

\section{Metode Penelitian}

Metode persilangan yang digunakan adalah persilangan secara berpasangan antara 14 individu pohon kelapa GSK dengan 3 individu pohon kelapa DMT sehingga diperoleh 42 kombinasi persilangan. Kelapa DMT 1188 disilangkan dengan kelapa GSK tandan nomor 1 , sedangkan kelapa DMT 1172 disilangkan dengan kelapa GSK tandan nomor 2, dan kelapa DMT 781 disilangkan denga kelapa GSK tandan nomor 3.

\section{Prosedur Kerja}

Koleksi pollen, Polen dikoleksi dari 3 individu pohon kelapa DMT yang telah mekar, yaitu dari bunga jantan yang pada bagian atasnya telah gugur sekitar $3 \mathrm{~cm}$. Tandan bunga yang telah mekar, dipotong, diberi label yang berisi tanggal pengambilan, lalu dibawa ke laboratorium untuk diproses sesuai dengan prosedur standar BALITKA. Tahapan prosesing polen tersebut meliputi proses pemipilan/ pembersihan, penggerusan, pengeringan, pengayakan, uji viabilitas, pengemasan dan penyimpanan.

Isolasi bunga betina, Sebelum bunga betina dari kelapa GSK reseptif, bunga jantannya diemaskulasi kemudian bunga betina tersebut diisolasi dengan menggunakan kerodong untuk menghindari terjadinya persilangan alami dengan bunga jantan dari tandan atau pohon yang lain.

Uji Viabilitas, Tahapan pengujian viabilitas dilakukan mulai dari pembuatan media tumbuh sampai pada pengujian viabilitas polen. Media tumbuh yang digunakan terdiri 0,5 gr agar, $100 \mathrm{cc}$ aquades, $10 \mathrm{gr}$ sukrosa, dan 3-4 butir asam borat. Bahan tersebut dimasak dalam gelas piala sampai mendidih dan kemudian dituangkan ke dalam petridish dengan tebal media sekitar $2-2,5 \mathrm{~mm}$. Setelah media dingin (sekitar 5 menit), polen ditabur merata ke permukaan media dengan menggunakan kuas kecil. Selanjutnya dibiarkan selama dua jam dan beberapa waktu kemudian dihitung viabilitas pollennya. Viabilitas polen diamati dengan mikroskop. Perhitungan viabilitas polen menurut Santos et. al. (1992) adalah dengan cara membagi media atas lima bidang. Pada setiap bidang diamati sebanyak 10 kali, sehingga jumlah pengamatan dalam satu petridish sebanyak 50 kali. Tingkat viabilitas polen dapat dihitung sebagai berikut : 
Viabilitas Polen $=$ Jumlah polen seluruhnya

Daya kecambah yang memenuhi syarat untuk digunakan adalah di atas 25 persen (Santos et. al. 1992). Polen kelapa DMT yang telah diamati viabilitasnya terdiri dari dua tandan untuk masing-masing nomor pohon sebab dibutuhkan jum-

Polinasi, banyak untuk persilangan. la bunga betinanya telah reseptif, yang ditandai dengan stigma yang mengeluarkan nektar. Polinasi dilakukan pada pagi hari. Dengan menggunakan kuas, polen yang telah diuji viabilitasnya diambil dan dilekatkan dengan cara dioleskan ke stigma.

Mengeluarkan kantong isolasi, Kantong isolasi dikeluarkan setelah stigma bunga betina mengalami nekrosis $\times 100 \%$

atau berubah warna menjadi hitam kecoklatan, yang umumnya terjadi enam atau tujuh hari sesudah polinasi.

Pengamatan, Pengamatan telah dilakukan terhadap jumlah bunga betina sebelum disilangkan, jumlah bunga betina yang gugur sesudah persilangan dan jumlah buah jadi hasil persilangan kelapa GSK $x$ DMT selama 3 bulan. Pengamatan juga telah dilakukan terhadap jumlah buah jadi hasil persilangan alami selama 3 bulan pada 3 nomor pohon kelapa Genjah Salak yaitu nomor pohon 6, 50 dan 70.

Analisis Data, Data yang diperoleh melalui pengamatan, dianalisis dengan menggunakan rumus berikut:

Total bunga betina yang menjadi buah bulan ke-n $\times 100 \%$

Persentase buah jadi = --.-- Total bunga betina awal

$(n=1,2$ dan 3$)$

\section{HASIL DAN PEMBAHASAN}

\section{Viabilitas Polen}

Polen yang digunakan dalam perakitan kelapa hibrida Genjah Salak $x$ Dalam Mapanget (GSK $\times$ DMT) adalah polen yang telah diuji viabilitasnya. Hasil pengujian viabilitas polen menunjukkan bahwa viabilitas polen kelapa Dalam Mapanget (DMT) dengan nomor pohon 1188 adalah 40 persen (tandan 1) dan $35,83 \%$ (tandan 2). Viabilitas polen kelapa DMT nomor pohon 1172 adalah 42,65\% (tandan 1) dan 38,36\% (tandan 2) serta viabilitas polen kelapa DMT nomor pohon 781 adalah $42,86 \%$ (tandan 1) dan
$38,78 \%$ (tandan 2). Viabilitas polen yang digunakan dapat mempengaruhi jumlah buah yang terbentuk. Polen yang memiliki viabilitas tinggi dapat membentuk buah yang banyak dan semakin kecil viabilitas maka tingkat keberhasilan dalam pembentukan buah juga sangat kecil (Santos et. al. 1992). Persentase buah jadi setelah periode tertentu merupakan indikator kualitas polen yang diuji (Johri dan Vasil, 1961 dalam Maskromo 1993).

Kualitas polen yang digunakan adalah masih memenuhi syarat, karena hasil persilangan (akan dibahas kemudian) kelapa GSK x DMT dibandingkan dengan hasil buah jadi dan persentasenya 
pada silangan alami tidak begitu jauh Dari persilangan alami pada kelapa Genjah Salak (GSK) dengan nomor pohon 6, 50 dan 70 diperoleh bahwa persentase buah jadi pada umur 3 bulan bervariasi dari 1 , $67-48,38 \%$ (Tabel 1 ).

Tabel 1. Persentase Buah Jadi Hasil Persilangan Alami Kelapa Genjah Salak (GSK) (The Become Fruit Rate From the Natural Crossing of GSK)

\begin{tabular}{|c|c|c|c|}
\hline $\begin{array}{c}\text { Nomor pohon } \\
\text { dan tandan }\end{array}$ & $\begin{array}{c}\text { Jumlah bunga } \\
\text { betina awal }\end{array}$ & $\begin{array}{c}\text { Jumlah buah jadi } \\
\text { umur } 3 \text { bulan (butir) }\end{array}$ & $\begin{array}{c}\text { Persentase buah jadi } \\
\text { umur } 3 \text { bulan (\%) }\end{array}$ \\
\hline $6(1)$ & 180 & 3 & 1,67 \\
$6(2)$ & 176 & 28 & 15,91 \\
$6(3)$ & 173 & 7 & 4,05 \\
$50(1)$ & 31 & 15 & 48,38 \\
$50(2)$ & 38 & 7 & 18,42 \\
$50(3)$ & 41 & 4 & 9,76 \\
$70(1)$ & 49 & 13 & 26,53 \\
$70(2)$ & 53 & 17 & 32,07 \\
\hline $70(3)$ & 48 & 4 & 8,33 \\
\hline
\end{tabular}

Ket : Nomor-nomor pohon kelapa GSK di atas diamati sebagai kontrol

\section{Jumlah Bunga Betina Kelapa GSK Sebelum Polinasi}

Jumlah bunga betina awal setiap individu pohon kelapa GSK yang ada pada tandan 1, 2 dan 3 berturut-turut adalah 25 - 157 bunga betina, 20 - 133 bunga betina, $30-147$ bunga betina. Jadi, jumlah bunga betina awal dari 14 individu pohon kelapa GSK pada tandan 1 sebanyak 1.039 bunga betina, tandan 2 sebanyak 978 bunga betina dan tandan 3 sebanyak 1.009 bunga betina (Tabel 2). Bunga betina pada tandan nomor 1 disilangkan dengan kelapa DMT 1188, sedangkan bunga betina pada tandan nomor 2 disilangkan dengan kelapa DMT 1172, dan bunga betina pada tandan nomor 3 disilangkan dengan kelapa DMT 781.
Jumlah Bunga Betina Kelapa GSK yang Menjadi Buah (Buah Jadi)

Pada Tabel 3 terlihat bahwa jumlah buah jadi dari persilangan antara kelapa GSK tandan ke-1 dengan DMT nomor pohon 1188 selama 1, 2 dan 3 bulan berturut-turut adalah 171, 154 dan 141 (Tabel 3). Buah jadi hasil persilangan antara kelapa GSK tandan ke-2 dengan DMT nomor pohon 1172 selama 1, 2 dan 3 bulan berturut-turut adalah 177 buah kelapa, 145 buah kelapa dan 137 buah kelapa (Tabel 4), serta buah jadi pada tandan ke-3 selama 1, 2 dan 3 bulan berturut-turut adalah 199 buah kelapa, 174 buah kelapa dan 171 buah kelapa (Tabel 5). 
Tabel 2. Pengamatan Jumlah Bunga Betina Awal Kelapa Genjah Salak (GSK) (The Observation of the Total Early Female Flower of Coconut GSK)

\begin{tabular}{|c|c|c|c|}
\hline \multirow{2}{*}{ Nomor Pohon } & \multicolumn{3}{|c|}{ Jumlah Bunga Betina Awal } \\
\cline { 2 - 4 } & Tandan 1 & Tandan 2 & Tandan 3 \\
7 & 121 & 96 & 147 \\
8 & 111 & 133 & 105 \\
10 & 59 & 78 & 63 \\
12 & 90 & 75 & 63 \\
14 & 89 & 90 & 81 \\
20 & 25 & 31 & 32 \\
28 & 69 & 67 & 81 \\
32 & 157 & 128 & 119 \\
41 & 49 & 47 & 37 \\
47 & 39 & 34 & 53 \\
49 & 66 & 58 & 49 \\
64 & 33 & 20 & 30 \\
65 & 98 & 95 & 114 \\
66 & 33 & 26 & 35 \\
\hline Total & 1.039 & 978 & 1.009 \\
\hline
\end{tabular}

Tabel 3. Jumlah Buah Jadi pada Persilangan Kelapa GSK x DMT 1188 (The Total Become Fruit in Crossing Coconut GSK x DMT 1188)

\begin{tabular}{|c|c|c|c|c|c|}
\hline No. & $\begin{array}{c}\text { Persilangan } \\
\text { GSK } \times \text { DMT }\end{array}$ & $\begin{array}{c}\text { Jumlah } \\
\text { Bunga Betina Awal }\end{array}$ & \multicolumn{3}{|c|}{$\begin{array}{c}\text { Jumlah Buah Jadi } \\
\text { Bulan ke- }\end{array}$} \\
\hline 1. & $7 \times 1188$ & 1 & 2 & 3 \\
\hline 2. & $8 \times 1188$ & 121 & 20 & 18 & 16 \\
\hline 3. & $10 \times 1188$ & 11 & 12 & 11 & 10 \\
4. & $12 \times 1188$ & 59 & 11 & 11 & 11 \\
\hline 5. & $14 \times 1188$ & 90 & 21 & 21 & 21 \\
6. & $20 \times 1188$ & 89 & 2 & 0 & 0 \\
\hline 7. & $28 \times 1188$ & 25 & 8 & 8 & 6 \\
8. & $32 \times 1188$ & 69 & 7 & 5 & 4 \\
\hline 9. & $41 \times 1188$ & 157 & 20 & 17 & 14 \\
10. & $47 \times 1188$ & 49 & 13 & 11 & 11 \\
\hline 11. & $49 \times 1188$ & 39 & 12 & 12 & 10 \\
12. & $64 \times 1188$ & 66 & 22 & 18 & 18 \\
\hline 13. & $65 \times 1188$ & 33 & 5 & 5 & 5 \\
\hline 14. & $66 \times 1188$ & 98 & 13 & 12 & 12 \\
\hline & Total & 33 & 5 & 5 & 3 \\
\hline
\end{tabular}


Tabel 4. Jumlah Buah Jadi pada Persilangan Kelapa GSK x DMT 1172 (The Total Become Fruit in Crossing of Coconut GSK $x$ DMT 1172)

\begin{tabular}{|c|c|c|c|c|c|}
\hline \multirow{3}{*}{ No. } & \multirow{3}{*}{$\begin{array}{l}\text { Persilangan } \\
\text { GSK x DMT }\end{array}$} & \multirow{3}{*}{$\begin{array}{c}\text { Jumlah } \\
\text { bunga betina } \\
\text { awal }\end{array}$} & \multicolumn{3}{|c|}{ Jumlah Buah Jadi } \\
\hline & & & \multicolumn{3}{|c|}{ Bulan ke- } \\
\hline & & & 1 & 2 & 3 \\
\hline 1. & $7 \times 1172$ & 96 & 18 & 12 & 12 \\
\hline 2. & $8 \times 1172$ & 133 & 8 & 5 & 5 \\
\hline 3. & $10 \times 1172$ & 78 & 11 & 11 & 11 \\
\hline 4. & $12 \times 1172$ & 75 & 24 & 24 & 24 \\
\hline 5. & $14 \times 1172$ & 90 & 18 & 17 & 16 \\
\hline 6. & $20 \times 1172$ & 31 & 8 & 6 & 3 \\
\hline 7. & $28 \times 1172$ & 67 & 13 & 13 & 12 \\
\hline 8. & $32 \times 1172$ & 128 & 11 & 10 & 10 \\
\hline 9. & $41 \times 1172$ & 47 & 9 & 3 & 3 \\
\hline 10. & $47 \times 1172$ & 34 & 5 & 4 & 3 \\
\hline 11. & $49 \times 1172$ & 58 & 22 & 19 & 18 \\
\hline 12. & $64 \times 1172$ & 20 & 6 & 5 & 5 \\
\hline 13. & $65 \times 1172$ & 95 & 16 & 13 & 13 \\
\hline 14. & $66 \times 1172$ & 26 & 8 & 3 & 2 \\
\hline \multicolumn{2}{|r|}{ Total } & 978 & 177 & 145 & 137 \\
\hline
\end{tabular}

Tabel 5. Jumlah Buah Jadi pada Persilangan Kelapa GSK $\times$ DMT 781 (The Total Become Fruit in Crossing of Coconut GSK $x$ DMT 781)

\begin{tabular}{|c|c|c|c|c|c|}
\hline \multirow{3}{*}{ No. } & \multirow{3}{*}{$\begin{array}{l}\text { Persilangan } \\
\text { GSK x DMT }\end{array}$} & \multirow{3}{*}{$\begin{array}{l}\text { Jumlah Bunga } \\
\text { Betina Awal }\end{array}$} & \multicolumn{3}{|c|}{ Jumlah Buah Jadi } \\
\hline & & & \multicolumn{3}{|c|}{ Bulan ke- } \\
\hline & & & 1 & 2 & 3 \\
\hline 1. & $7 \times 781$ & 147 & 23 & 23 & 23 \\
\hline 2. & $8 \times 781$ & 105 & 22 & 22 & 21 \\
\hline 3. & $10 \times 781$ & 63 & 7 & 3 & 3 \\
\hline 4. & $12 \times 781$ & 63 & 9 & 7 & 7 \\
\hline 5. & $14 \times 781$ & 81 & 24 & 22 & 22 \\
\hline 6. & $20 \times 781$ & 32 & 5 & 5 & 5 \\
\hline 7. & $28 \times 781$ & 81 & 19 & 17 & 16 \\
\hline 8. & $32 \times 781$ & 119 & 26 & 20 & 20 \\
\hline 9. & $41 \times 781$ & 37 & 13 & 10 & 10 \\
\hline 10. & $47 \times 781$ & 53 & 12 & 11 & 11 \\
\hline 11. & $49 \times 781$ & 49 & 12 & 12 & 12 \\
\hline 12. & $64 \times 781$ & 30 & 4 & 3 & 3 \\
\hline 13. & $65 \times 781$ & 114 & 21 & 18 & 17 \\
\hline 14. & $66 \times 781$ & 35 & 2 & 1 & 1 \\
\hline & Total & 1009 & 199 & 174 & 171 \\
\hline
\end{tabular}


Persentase buah jadi hasil persilangan setiap individu pohon untuk kelapa GSK tandan ke-1 dengan DMT nomor pohon 1188 selama 3 bulan bervariasi dari 0,00-27,27\% (Tabel 6). Persentase buah jadi 0,00\% disebabkan karena semua buah jadi kelapa GSK dengan nomor pohon 14 mengalami keguguran. Untuk persilangan kelapa GSK tandan ke-2 dengan DMT nomor pohon 1172 selama 3 bulan, persentase buah jadi setiap individu pohon bervariasi dari $3,76-32 \%$
(Tandan 7). Sedangkan untuk persilangan kelapa GSK tandan ke-3 dengan DMT nomor pohon 781 selama 3 bulan bervariasi dari 2,86-27,16\% (Tabel 8 ). Hasil pengamatan ini sesuai dengan Thampan, (1981) bahwa jumlah bunga betina yang berkembang menjadi buah dapat bervariasi yakni antara 25 - 40 persen dari total bunga betina, karena dipengaruhi oleh faktor iklim, varietas, kondisi tanah maupun potensi hasil tanaman itu sendiri.

Tabel 6. Persentase buah jadi hasil persilangan kelapa GSK x DMT1188 (The Become Fruit Rate From the Crossing of Coconut GSK x DMT 1188)

\begin{tabular}{|c|c|c|c|c|}
\hline & & \multicolumn{3}{|c|}{ Persentase Buah Jadi } \\
\cline { 2 - 4 } No. & Persilangan GSK x DMT & \multicolumn{3}{|c|}{ Bulan } \\
\hline 1. & $7 \times 1188$ & 1 & 2 & 3 \\
\hline 2. & $8 \times 1188$ & 16,53 & 14,88 & 13,22 \\
3. & $10 \times 1188$ & 10,81 & 9,91 & 9,01 \\
4. & $12 \times 1188$ & 18,64 & 18,64 & 18,64 \\
5. & $14 \times 1188$ & 23,33 & 23,33 & 23,33 \\
6. & $20 \times 1188$ & 2,25 & 0 & 0 \\
7. & $28 \times 1188$ & 32 & 32 & 24 \\
8. & $32 \times 1188$ & 10,14 & 7,25 & 5,79 \\
9. & $41 \times 1188$ & 12,74 & 10,83 & 8,92 \\
10. & $47 \times 1188$ & 26,53 & 22,45 & 22,45 \\
11. & $49 \times 1188$ & 30,77 & 30,77 & 25,64 \\
12. & $64 \times 1188$ & 33,33 & 27,27 & 27,27 \\
13. & $65 \times 1188$ & 15,15 & 15,15 & 15,15 \\
14. & $66 \times 1188$ & 13,27 & 12,24 & 12,24 \\
\hline & & 15,15 & 15,15 & 9,09 \\
\hline
\end{tabular}


Tabel 7. Persentase Buah Jadi Hasil Persilangan Kelapa GSK x DMT 1172 (The Become Fruit Rate From the Crossing of Coconut GSK x DMT 1172)

\begin{tabular}{|c|c|c|c|c|}
\hline & & \multicolumn{3}{|c|}{ Persentase Buah Jadi } \\
\cline { 3 - 5 } No. & Persilangan GSK x DMT & \multicolumn{3}{|c|}{ Bulan } \\
\cline { 3 - 5 } & & 1 & 2 & 3 \\
\hline 1. & $7 \times 1172$ & 18,75 & 12,5 & 12,5 \\
2. & $8 \times 1172$ & 6,02 & 3,76 & 3,76 \\
3. & $10 \times 1172$ & 14,10 & 14,10 & 14,10 \\
4. & $12 \times 1172$ & 32 & 32 & 32 \\
\hline 5. & $14 \times 1172$ & 20 & 18,89 & 17,77 \\
6. & $20 \times 1172$ & 25,81 & 19,35 & 9,68 \\
7. & $28 \times 1172$ & 19,40 & 19,40 & 17,91 \\
8. & $32 \times 1172$ & 8,59 & 7,81 & 7,81 \\
9. & $41 \times 1172$ & 19,15 & 6,38 & 6,38 \\
10. & $47 \times 1172$ & 14,71 & 11,76 & 8,82 \\
11. & $49 \times 1172$ & 37,93 & 35,76 & 31,03 \\
12. & $64 \times 1172$ & 30 & 25 & 25 \\
13. & $65 \times 1172$ & 16,84 & 13,68 & 13,68 \\
14. & $66 \times 1172$ & 30,77 & 11,54 & 7,69 \\
\hline
\end{tabular}

Hasil observasi yang dilakukan di Kebun Percobaan Paniki, Sulawesi Utara selama periode 1982-1983 (periode kemarau panjang) diperoleh persentase buah jadi hanya 18,1 persen (Novarianto, Kangiden, Tampake dan Rompas 1984). Selanjutnya hasil penelitian Novarianto, dkk. (1984) tentang waktu penyerbukan dan penggunaan talcum terhadap pembentukan benih kelapa hibrida, persentase buah pada umur 1, 2 dan 3 bulan berturut-turut adalah 22,3 persen, 18,4 persen dan 17 persen.

Hasil penelitian Maskromo dan Tampake (1993) pada persilangan menggunakan polen kelapa Dalam Tenga (DTA), kelapa Dalam Bali (DBI), kelapa Dalam Palu (DPU) dan kelapa Dalam Sawarna (DSA) terhadap kelapa Genjah Kuning Nias (GKN) diperoleh rataan persentase buah jadi pada umur 1 bulan sesudah penyerbukan adalah 15,6-49,2 \%.
Persentase keberhasilan buah jadi dalam persilangan yang rendah dapat diakibatkan karena terjadinya keguguran selama pembentukan buah. Sampai pada umur 6 minggu, buah kelapa yang terbentuk akan mengalami keguguran sampai 70 persen (Santos et. al. 1992). Bahkan menurut Thampan (1981), sekitar 2/3- 3/4 (66,67 - 75 persen) bunga betina yang mengalami fertilisasi akan gugur hingga mencapai umur 3 bulan. Dari buah yang tertinggal pada umur 3 bulan kemungkinan masih akan gugur lagi sampai pada saat panen.

Tingkat keberhasilan pembentukan buah tanaman kelapa juga sangat dipengaruhi oleh faktor lingkungan seperti kondisi iklim. Salah satu faktor iklim yang menguntungkan adalah curah hujan. Waktu pelaksanaan penelitian yaitu dari bulan November sampai dengan bulan Februari termasuk dalam kategori bulan basah sebab terdapat curah hujan yang 
cukup tinggi. Hal tersebut dapat memungkinkan terjadinya hambatan dalam pembentukan buah pada tanaman kelapa.

Menurut Fehr dan Hadley (1980), keguguran bakal buah dapat disebabkan karena gagalnya pembentukan embrio yang terjadi karena adanya hambatan genetik berupa inkompatibilitas gametophytik yaitu hambatan perkembangan tabung sari menuju kantung embrio sehingga embrio tidak normal.

Tabel 8. Persentase Buah Jadi Hasil Persilangan Kelapa GSK x DMT 781 (The Become Fruit Rate From the Crossing of Coconut GSK $\times$ DMT 781)

\begin{tabular}{|c|c|c|c|c|}
\hline \multirow{2}{*}{ No. } & \multirow{3}{*}{ Persilangan GSK x DMT } & \multicolumn{3}{|c|}{ Persentase Buah Jadi } \\
\cline { 3 - 5 } & & 1 & 2 & 3 \\
\hline 1. & $7 \times 781$ & 15,65 & 15,65 & 15,65 \\
2. & $8 \times 781$ & 20,95 & 20,95 & 20 \\
3. & $10 \times 781$ & 11,11 & 4,76 & 4,76 \\
4. & $12 \times 781$ & 14,28 & 11,11 & 11,11 \\
5. & $14 \times 781$ & 29,63 & 27,16 & 27,16 \\
6. & $20 \times 781$ & 15,62 & 15,62 & 15,62 \\
\hline 7. & $28 \times 781$ & 23,46 & 20,99 & 19,75 \\
8. & $32 \times 781$ & 21,84 & 16,81 & 16,81 \\
9. & $41 \times 781$ & 35,14 & 27,03 & 27,03 \\
10. & $47 \times 781$ & 22,64 & 20,75 & 20,75 \\
11. & $49 \times 781$ & 24,49 & 24,49 & 24,49 \\
12. & $64 \times 781$ & 13,33 & 10 & 10 \\
13. & $65 \times 781$ & 18,42 & 15,79 & 14,91 \\
\hline 14. & $66 \times 781$ & 5,71 & 2,86 & 2,86 \\
\hline
\end{tabular}

Memasuki bulan ke-3, persentase buah jadi menunjukkan penurunan yang lebih kecil. Hal ini disebabkan oleh karena bakal buah yang gugur akibat gagalnya proses pembuahan semakin sedikit, sehingga buah yang tersisa diharapkan akan dapat menjadi buah dewasa jika kondisi lingkungan mendukung. Keguguran bakal buah juga dapat disebabkan karena adanya kegagalan dalam penyerbukan. Walaupun demikian hasil pengamatan persilangan dan pengujian kelapa GKN x Dalam (Tenga, Takome, Sawarna, Igo, Duku, WAT, Rennel, Polynesia) sampai pada Maret 1992 menunjukkan bahwa persentase buah jadi umur 2 bulan berkisar antara 13,03 - 16,22 persen, tergolong baik untuk persilangan buatan (Mahmud 1993).

\section{KESIMPULAN DAN SARAN}

\section{Kesimpulan}

Persentase buah jadi hasil persilangan antara 14 individu pohon kelapa Genjah Salak (GSK) dan 3 individu pohon kelapa Dalam Mapanget (DMT) nomor pohon 1188, 1172 dan 781 pada umur 3 bulan berturut-turut adalah bervariasi dari $0,00-27,27$ persen, $3,76-32$ persen dan 2,86-27,16 persen. Dengan demikian persentase keberhasilan persi- 
langan yang terendah terdapat pada kombinasi persilangan antara kelapa GSK nomor pohon 14 dan DMT nomor pohon 1188 dengan jumlah 0,00 persen sedangkan persentase keberhasilan tertinggi terdapat pada kombinasi persilangan antara kelapa GSK nomor pohon 12 dan DMT nomor pohon 1172 dengan jumlah 32 persen.

\section{Saran}

Perlu dilakukan pengamatan lanjutan mengenai persentase buah jadi hasil persilangan kelapa Genjah Salak dengan Dalam Mapanget (GSK x DMT) sampai waktu panen.

\section{UCAPAN TERIMA KASIH}

Penelitian ini dibiayai oleh Proyek Penelitian Hibah Bersaing Perguruan Tinggi, DIKTI-DEPDIKNAS Tahun Anggaran 2006 atas nama Dr. Ir. Semuel D. Runtunuwu.

\section{DAFTAR PUSTAKA}

Fehr, R.W, and H.H. Hadley. 1980. Hybridization Of Crop Plants. American Society Of Agronomy and Crop Science Society Of America. Publishers Madison. Winconsin. USA.

Mahmud, Z. 1993. Highlight Hasil Penelitian Balai Penelitian Kelapa Pelita V. Prosiding Konferensi Nasional Kelapa III. Yogyakarta.

Maskromo, I. dan H. Tampake. 1993. Pengaruh Umur Bunga Jantan Beberapa Jenis Kelapa Dalam Terhadap Persentase Buah Jadi Pada Persilangan Buatan
Dengan Genjah Kuning Nias. Jurnal Penelitian Kelapa BALITKA. Manado.

Novarianto, $H$. D.I. Kangiden, $H$ Tampake, dan T. Rompas. 1984. Penyerbukan Buatan Pada Kelapa. Jurnal Puslitbangtri. Bogor.

Novarianto, H., Miftahorrachman, dan J. Kumaunang. 1997. Peluang Bisnis Pengembangan Benih Unggul Kelapa. Prosiding Temu Usaha Perkelapaan Nasional. Badan Litbang, BALITKA. Manado.

Novarianto, H. 2002. Hasil-Hasil Penelitian Pemuliaan Kelapa. Prosiding Seminar Regional Bioteknologi dan Pemuliaan Tanaman Kelapa. BALITKA. Manado.

Novarianto, H. 2003. Monograf Plasma Nutfah Kelapa Indonesia. Badan Litbang Pertanian, BALITKA. Manado.

Runtunuwu S.D., M.S. Sinaga, dan A. Hartana. 1999. Seleksi Ketahanan tanaman Kelapa Terhadap Gugur Buah (Phytophtora palmivora BUTLER). Buletin Hama dan Penyakit Tumbuhan. Jurusan HPT IPB. Bogor.

Santos, G.A., P.A. Batugal, A. Othman, L. Baurdoin, and J.P. Labouisse. 1992. Manual On Standardized Research Technigues In Coconut Breeding. IPGRI. COGENT. 
Singkoh, M. 2005. Studi Keragaman Pola Pita DNA Dan Keseragaman Populasi Kelapa Genjah Salak Berdasarkan Penanda RAPD. Skripsi. Fakultas Pertanian UNSRAT. Manado.

Sual, M. 2005. Keragaman Bunga Betina Dalam Populasi Kelapa Genjah Salak Di KP. BALITKA Kima Atas. Skripsi. Fakultas Pertanian UNSRAT. Manado.
Thampan, P.K. 1981. Handbook on Coconut Palm. Oxford \& IBH Publishing. Co. Calcuta. India

Tenda, E.T., H.G. Lengkey, J. Kumaunang. 1997. Produksi Dan Kualitas Tiga Kultivar Kelapa Genjah Dan Tiga Kultivar Kelapa Dalam. Jurnal penelitian tanaman industri. Bogor. 